\title{
Impact of post-dilatation on the reduction of paravalvular leak and mortality after transcatheter aortic valve implantation
}

\author{
Paweł Kleczyński, Artur Dziewierz, Marzena Daniec, Maciej Bagieński, Łukasz Rzeszutko, \\ Danuta Sorysz, Jarosław Trębacz, Robert Sobczyński, Marek Tomala, Dariusz Dudek \\ Institute of Cardiology, Jagiellonian University, Medical College, Krakow, Poland
}

\begin{abstract}
A bstract
Background: Post-implantation paravalvular leak (PVL) remains a significant complication of transcatheter aortic valve implantation (TAVI). More importantly, its occurrence may impact long-term mortality.

Aim: We sought to evaluate the effects of balloon post-dilatation (PD) on the reduction of PVL and mortality in patients undergoing TAVI.

Methods: A total of 101 consecutive patients undergoing TAVI were enrolled. Angiography, echocardiography, and the aortic regurgitation index (ARI) were used to assess the severity of PVL before and after balloon PD. Patients were divided into two groups based whether or not PD after TAVI was performed. Reduction of PVL, change of ARI, and clinical outcomes were assessed.

Results: Balloon post-dilatation was performed in 23 (22.8\%) patients. In 95.6\%, PVL reduction was successful (no or mild PVL). PD increased the ARI from 23.4\% (22.4-24.0) to 27.1\% (26.1-28.3); $\mathrm{p}<0.001$. Thirty-day mortality rate was $14.1 \%$ in the PD (-) group vs. $0.0 \%$ in the PD (+) group; $p=0.07$. One-year mortality $(21.8 \%$ vs. $4.3 \%, p=0.97)$ and procedural stroke rate $(7.7 \%$ vs. $8.7 \%, p=0.99)$ were not different between the groups.

Conclusions: Balloon post-dilatation may be a safe and effective technique to reduce moderate to severe PVL after TAVI.

Key words: aortic stenosis, transcatheter aortic valve implantation, paravalvular leak, post-dilatation
\end{abstract}

Kardiol Pol 2017; 75, 8: 742-748

\section{INTRODUCTION}

Transcatheter aortic valve implantation (TAVI) is a less invasive treatment option for elderly, high-risk patients with symptomatic severe aortic stenosis (AS) than surgical aortic valve replacement. TAVI improves survival and quality of life in inoperable patients as compared to medical treatment of severe AS [1-3]. However, post-implantation paravalvular leak (PVL) remains a significant TAVI-related complication [4]. Importantly, the presence of PVL may worsen clinical outcomes of patients undergoing TAVI [5]. It is present in up to $70 \%$ of all patients undergoing TAVI, and more than mild PVL has been reported in about 10-15\% of all TAVI patients [1, 6-14]. Angiography and echocardiography are useful tools to quantify the degree of PVL immediately after deployment of the prosthesis and can be used to identify patients who might benefit from optimisation techniques. Combining invasive haemodynamic measurements with assessment of the aortic regurgitation index (ARI) and imaging may be even more accurate than imaging alone $[9,15,16]$. Balloon post-dilatation (PD) can reduce PVL by achieving a better expansion of the prosthesis and optimal sealing of the paravalvular space. Valve-in-valve implantation is another option to overcome significant PVL, especially if the implantation position is more deep or more shallow than expected [17-19]. However, data on the impact of PD on long-term outcomes after TAVI are scarce. The aim of our study was to evaluate whether balloon PD is safe and effective in reducing PVL after TAVI and to assess its impact on mortality. 


\section{METHODS}

A total of 101 consecutive high-risk elderly patients with severe symptomatic AS undergoing TAVI were enrolled between November 2008 and November 2014. Patient screening and selection was performed by a multidisciplinary Heart Team supported by clinical and imaging resources. TAVI procedures were performed using Edwards Sapien, Edwards Sapien XT, Edwards Sapien 3 (Edwards Lifesciences, Irvine, USA) Medtronic Corevalve, EvolutR (Medtronic Inc., Minneapolis, USA), and JenaValve (JenaValve Technology, Munich, Germany). Access routes were transfemoral, transapical, and direct aortic. Procedures were performed under general anaesthesia or sedation. Balloon aortic valvuloplasty was performed in each case. Baseline characteristics, and procedural and outcomes data was collected and analysed prospectively. After valve deployment, the degree of PVL was routinely assessed by aortic root angiography $(30 \mathrm{~mL}$ contrast dye at a flow rate of $15 \mathrm{~mL} / \mathrm{s}$ ) according to the visually estimated density of opacification of the left ventricle (LV) into three degrees adapted from the VARC-2 criteria: mild (reflow of contrast in the outflow tract and middle portion of the LV but clearing with each beat), moderate (reflow of contrast in the whole LV cavity with incomplete washout in a single beat and faint opacification of the entire LV over several cardiac cycles), and severe (opacification of the entire LV with the same intensity as in the aorta and persistence of the contrast after a single beat) and with echocardiography [20]. In all patients, a $6 \mathrm{Fr}$ pigtail catheter was placed approximately $2 \mathrm{~cm}$ above the aortic valve. In all patients, haemodynamics were assessed and calculation of the ARI was performed to quantify the extent of PVL more precisely and to have a point of reference before PD was carried out. The ARI was calculated according to the following formula: ([diastolic blood pressure - left ventricular end-diastolic pressure]/systolic blood pressure) $\times 100 \%$, from 5 to 10 min after valve deployment or PD. A detailed description of ARI assessment and its limitations were described previously [9]. In patients with more than mild angiographically detected PVL and/or an ARI < 25\%, PVL was evaluated by echocardiography, preferably transesophageal echocardiography, and if confirmed, a PD was performed. In patients with suboptimal frame expansion causing more than mild PVL, PD was performed to obtain a better expansion of the prosthesis stent frame and a better sealing of the paravalvular space. PD was performed by adding 1-2 cc of contrast dye to the delivery system of balloon expandable valves used during TAVI. For self-expandable prostheses, a 1:1 balloon to aortic native annulus was used for PD (Osypka VACS II, Osypka AG, Germany). The primary endpoint of our study was the change of the PVL grade and ARI after PD in patients undergoing TAVI. Secondary endpoints were the severity of PVL defined according to the VARC-2 criteria, all-cause mortality at 30 days and one year, and post-procedural stroke rate. Patients were divided into two groups based whether or not balloon PD after TAVI was performed. The study protocol was approved by the institutional Ethical Board.

\section{Statistical analysis}

Results are presented as numbers of patients (percentages) or the median (interquartile range $[\mathrm{IQR}]$ ) where applicable. Differences between groups were tested using $\chi^{2}$ test and the Fisher's exact test for dichotomous variables, and the Mann-Whitney U-test for continuous variables. Changes in the ARI between pre, immediately after, and post TAVI were analysed with Wilcoxon signed-rank test. Changes in the proportions of patients with none, mild, moderate, and severe PVL between pre, immediately after, and post TAVI were tested with $\chi^{2}$ test. In addition, changes in the proportions of patients with "none/mild" vs. "moderate/severe" PVL were analysed using McNemar's test. The difference in mortality between patients with and without PD after TAVI during 12-month follow-up was assessed by the Kaplan-Meier method and log-rank test. All tests were two-tailed, and a p value $<0.05$ was considered statistically significant. All statistical analysis was performed using SPSS 15.0 (SPSS, Inc., Chicago, IL, USA).

\section{RESULTS}

A total of 101 consecutive patients underwent TAVI. Baseline characteristics are shown in Table 1. PD was performed in $23(22.8 \%)$ patients. Patients were divided based on the need for PD into two groups: with [PD (+), 23 patients] and without PD [PD (-), 78 patients]. Procedural data are summarised in Table 2. No annular rupture was observed in the PD $(+)$ group. The transfemoral access was used in $73.1 \%$ of patients in the PD (-) group and in $91.3 \%$ in the PD $(+)$ group $(p<0.001)$. Interestingly, the fluoroscopy time, radiation dose, and contrast medium volume were higher in patients without PD (Table 2). No difference in the size of prosthesis, annulus dimensions, and cover index between groups was found. In $95.6 \%$ of patients PVL reduction was successful (no or mild PVL). Detailed data presenting severity of PVL before and immediately after prosthesis deployment and at the end of the TAVI procedure after PD is shown in Figure 1A (for all patients) and Figure 1B (for patients requiring PD). PD increased the ARI from 23.4\% (22.4-24.0) to $27.1 \%$ (26.1-28.3); $p<0.001$. No coronary obstruction in the PD $(+)$ group was noted. A trend towards increased 30-day mortality was observed in the PD (-) group $(14.1 \%$ vs. $0.0 \% ; p=0.07)$. In contrast, no differences in stroke $(7.7 \%$ vs. $8.7 \% ; p=0.99)$ and myocardial infarction (3.8\% vs. $4.3 \% ; p=0.99)$ rates were observed. One-year mortality rate $(21.8 \%$ vs. $4.3 \%, p=0.07$, Fig. 2$)$ was higher in the PD (-) group, but no statistical significance was found.

We also performed a subanalysis of balloon-expandable valves (Edwards and Jena Valve) vs. self-expandable valves (Corevalve) in terms of PVL occurrence after prosthesis deployment, PD, and access site. More than mild PVL after prosthesis 
Table 1. Baseline characteristics

\begin{tabular}{|c|c|c|c|c|}
\hline & $\begin{array}{l}\text { All patients } \\
(n=101)\end{array}$ & $\begin{array}{l}\text { Post-dilatation (-) } \\
\qquad(n=78)\end{array}$ & $\begin{array}{l}\text { Post-dilatation }(+) \\
\qquad(n=23)\end{array}$ & p \\
\hline Age, median (IQR) [years] & $81.0(76.0-84.0)$ & $81.0(77.0-84.0)$ & $82.0(72.5-84.0)$ & 0.80 \\
\hline Age $\geq 80$ years & $59(58.4 \%)$ & $46(59.0 \%)$ & $13(56.5 \%)$ & 0.83 \\
\hline Men & $40(39.6 \%)$ & $31(39.7 \%)$ & $9(39.1 \%)$ & 0.96 \\
\hline Body mass index, median (IQR) $\left[\mathrm{kg} / \mathrm{m}^{2}\right]$ & $28.0(25.2-31.1)$ & $27.9(25.6-30.6)$ & $27.8(25.6-31.3)$ & 0.95 \\
\hline eGFR median, (IQR) [mL/min/1.73 m²] & $61.0(39.0-81.0)$ & $60.0(43.0-76.5)$ & $70.0(43.5-81.0)$ & 0.32 \\
\hline NYHA class: & & & & 0.019 \\
\hline I & $0(0.0 \%)$ & $0(0.0 \%)$ & $0(0.0 \%)$ & \\
\hline$\|$ & $17(16.8 \%)$ & $9(11.5 \%)$ & $8(34.8 \%)$ & \\
\hline III & $74(73.3 \%)$ & $62(79.5 \%)$ & $12(52.2 \%)$ & \\
\hline IV & $10(9.9 \%)$ & $7(9.0 \%)$ & $3(13.0 \%)$ & \\
\hline Arterial hypertension & $94(93.1 \%)$ & $71(91.0 \%)$ & $23(100.0 \%)$ & 0.35 \\
\hline Diabetes mellitus & $35(34.7 \%)$ & $28(35.9 \%)$ & $7(30.4 \%)$ & 0.80 \\
\hline Atrial fibrillation & $35(34.7 \%)$ & $24(30.8 \%)$ & $11(47.8 \%)$ & 0.13 \\
\hline History of Ml & $31(30.7 \%)$ & $25(32.1 \%)$ & $6(26.1 \%)$ & 0.59 \\
\hline $\mathrm{PCl}$ & $29(28.7 \%)$ & $21(26.9 \%)$ & $8(34.8 \%)$ & 0.46 \\
\hline CABG & $17(16.8 \%)$ & $14(17.9 \%)$ & $3(13.0 \%)$ & 0.76 \\
\hline Chronic total occlusion & $9(8.9)$ & $9(11.5)$ & $0(0.0)$ & 0.11 \\
\hline COPD & $12(11.9 \%)$ & $9(11.5 \%)$ & $3(13.0 \%)$ & 0.99 \\
\hline Stroke/transient ischaemic attack & $10(9.9 \%)$ & $9(11.5 \%)$ & $1(4.3 \%)$ & 0.45 \\
\hline Pacemaker & $11(11.1 \%)$ & $10(13.2 \%)$ & $1(4.3 \%)$ & 0.45 \\
\hline Logistic Euroscore I, median (IQR) [\%] & $14.0(10.0-22.5)$ & $17.0(10.0-23.0)$ & $11.0(8.0-14.5)$ & 0.08 \\
\hline STS, median (IQR) [\%] & $12.0(5.0-24.0)$ & $9.0(5.0-20.0)$ & $21.0(8.5-30.0)$ & 0.13 \\
\hline TG max, median (IQR) [mm Hg] & $87.0(71.5-108.0)$ & $87.0(70.5-106.5)$ & $79.5(62.0-90.0)$ & 0.19 \\
\hline TG mean, median (IQR) [mm Hg] & $51.0(42.5-66.5)$ & $52.0(43.0-65.0)$ & $48.5(38.0-52.0)$ & 0.26 \\
\hline AVA, median (IQR) $\left[\mathrm{cm}^{2}\right]$ & $0.6(0.4-0.8)$ & $0.7(0.6-0.8)$ & $0.8(0.6-1.0)$ & 0.20 \\
\hline LVEF, median (IQR) [\%] & $60.0(47.5-65.0)$ & $60.0(47.0-65.0)$ & $62.0(48.0-65.0)$ & 0.51 \\
\hline Aortic regurgitation: & & & & 0.11 \\
\hline 0 & 35 (34.7\%) & $24(30.8 \%)$ & $11(47.8 \%)$ & \\
\hline 1 & $51(50.5 \%)$ & $44(56.4 \%)$ & $7(30.4 \%)$ & \\
\hline 2 & $14(13.9 \%)$ & $9(11.5 \%)$ & $5(21.7 \%)$ & \\
\hline 3 & $1(1.0 \%)$ & $1(1.3 \%)$ & $0(0.0 \%)$ & \\
\hline
\end{tabular}

AVA — aortic valve area; CABG — coronary artery bypass graft; COPD — chronic obstructive pulmonary disease; eGFR — estimated glomerular filtration rate; IQR — interquartile range; LVEF — left ventricular ejection fraction; MI — myocardial infarction; NYHA — New York Heart Association; $\mathrm{PCl}$ - percutaneous coronary intervention; STS - The Society of Thoracic Surgeons; TG — transvalvular gradient

deployment, after PD, and at the end of TAVI procedure were present in 16 (19.8\%), 16 (19.8\%), and two (2.5\%) patients in the balloon expandable valves group vs. eight (40.0\%), seven $(35.0 \%)$, and four $(20.0 \%)$ patients in the self-expanding valves group $(p=0.08 ; p=0.23 ; p=0013)$, respectively.

\section{DISCUSSION}

Many factors may contribute significantly to clinical outcomes after TAVI. For instance, the presence of coronary artery disease and the occurence periprocedural ischaemic complications may worsen clinical outcomes [21, 22]. Another potential factor is the presence of PVL after TAVI. Importantly, PVL remains the factor linked directly to the procedure itself. Moderate-to-severe PVL had been previously identified as an independent predictor of death between 30 days and one year after TAVI with Medtronic CoreValve [23]. An impact of PVL on medium-term prognosis has recently been demonstrated also for the Edwards SAPIEN prosthesis [7]. Meta-analyses of multiple studies in the high-risk populations showed that moderate or severe PVL is an important determinant of mortality regardless of the implanted 
Table 2. Procedural and follow-up data

\begin{tabular}{|c|c|c|c|c|}
\hline & $\begin{array}{l}\text { All patients } \\
(n=101)\end{array}$ & $\begin{array}{l}\text { Post-dilatation (-) } \\
\qquad(\mathrm{n}=78)\end{array}$ & $\begin{array}{l}\text { Post-dilatation }(+) \\
\qquad(n=23)\end{array}$ & $\mathbf{p}$ \\
\hline Transfemoral access & $78(77.2 \%)$ & $57(73.1 \%)$ & $21(91.3 \%)$ & $<0.001$ \\
\hline Transapical access & $21(20.8 \%)$ & $21(26.9 \%)$ & $0(0.0 \%)$ & \\
\hline Transaortic access & $2(2.0 \%)$ & $0(0.0 \%)$ & $2(8.7 \%)$ & \\
\hline Medtronic CoreValve & $20(19.8 \%)$ & $13(16.7 \%)$ & $7(30.4 \%)$ & 0.22 \\
\hline Edwards SAPIEN & $77(76.2 \%)$ & $61(78.2 \%)$ & $16(69.6 \%)$ & \\
\hline Jena Valve & $4(4.0 \%)$ & $4(5.1 \%)$ & $0(0.0 \%)$ & \\
\hline Prosthesis size: & & & & 0.86 \\
\hline $23 \mathrm{~mm}$ & $16(15.8 \%)$ & $14(17.9 \%)$ & $2(8.7 \%)$ & \\
\hline $25 \mathrm{~mm}$ & $2(2.0 \%)$ & $2(2.6 \%)$ & $0(0.0 \%)$ & \\
\hline $26 \mathrm{~mm}$ & $48(47.5 \%)$ & $36(46.2 \%)$ & $12(52.2 \%)$ & \\
\hline $27 \mathrm{~mm}$ & $1(1.0 \%)$ & $1(1.3 \%)$ & $0(0.0 \%)$ & \\
\hline $29 \mathrm{~mm}$ & $29(28.7 \%)$ & $21(26.9 \%)$ & $8(34.8 \%)$ & \\
\hline $31 \mathrm{~mm}$ & $5(5.0 \%)$ & $4(5.1 \%)$ & $1(4.3 \%)$ & \\
\hline Prosthesis size, median (IQR) [mm] & $26.0(26.0-29.0)$ & $26.0(26.0-29.0)$ & $26.0(26.0-29.0)$ & 0.35 \\
\hline Annulus size, median (IQR) [mm] & $23.0(22.0-25.0)$ & $23.0(21.8-25.0)$ & $23.0(22.0-24.8)$ & 0.50 \\
\hline Cover index, median (IQR) [\%] & $11.5(8.7-15.4)$ & $11.5(8.7-15.3)$ & $13.5(10.3-15.4)$ & 0.33 \\
\hline Ellipticity index, median (IQR) [\%] & $1.2(1.0-1.2)$ & $1.2(1.0-1.2)$ & $1.2(1.0-1.3)$ & 0.77 \\
\hline AR index before, median (IQR) [\%] & $28.4(25.0-29.9)$ & $29.4(27.9-30.5)$ & $23.4(22.4-24.0)$ & $<0.001$ \\
\hline AR index before $<25 \%$ & $25(24.8 \%)$ & $4(5.1 \%)$ & $21(91.3 \%)$ & $<0.001$ \\
\hline AR index after, median (IQR) [\%] & $27.1(26.1-28.3)$ & - & $27.1(26.1-28.3)$ & - \\
\hline AR index after $<25 \%$ & $1(0.9 \%)$ & - & $1(4.3 \%)$ & - \\
\hline Radiation dose, median (IQR) [mGy] & $733.0(634.0-831.5)$ & $783.0(678.0-841.0)$ & $631.0(606.0-739.5)$ & $<0.001$ \\
\hline Contrast medium load, median (IQR) [mL] & $100.0(75.0-150.0)$ & $100.0(100.0-150.0)$ & $75.0(75.0-75.0)$ & $<0.001$ \\
\hline Fluoroscopy time, median (IQR) [min] & $14.0(13.0-15.5)$ & $14.0(13.0-16.0)$ & $13.0(12.0-14.0)$ & 0.013 \\
\hline TG max after TAVI, median (IQR) [mm Hg] & $14.5(10.8-19.0)$ & $14.0(10.6-19.0)$ & $14.0(10.0-19.0)$ & 0.93 \\
\hline TG mean after TAVI, median (IQR) [mm Hg] & $8.0(6.0-10.0)$ & $8.0(6.0-9.6)$ & $7.5(6.0-11.0)$ & 0.75 \\
\hline LVEF after, median (IQR) [\%] & $49.0(42.8-60.0)$ & $50.0(44.0-60.0)$ & $47.0(38.5-49.5)$ & 0.09 \\
\hline
\end{tabular}

AR — aortic regurgitation; IQR — interquartile range; LVEF — left ventricular ejection fraction; TAVI — transcatheter aortic valve implantation; TG - transvalvular gradient

valve type $[24,25]$. The occurrence of PVL after TAVI might be more frequent after direct valve implantation without balloon $\mathrm{PD}$, resulting in more frequent PD afterwards [12].

We confirmed that balloon PD can effectively and safely reduce the degree of PVL after TAVI when the primary result of the implantation of the prosthesis is not optimal. PD has been performed due to frame under-expansion in most cases, and it was required in $22.7 \%$ of patients. This rate was quite similar to that reported in previous studies with a post-dilation rate of $30 \%$ to $38 \%$ after implantation of self-expanding prostheses and $28 \%$ to $41 \%$ for balloon-expandable valves [15, $17,23,24,26]$. PD might be associated with a higher rate of cardiovascular complications, conduction disturbances, annulus rupture, coronary obstruction, and cerebral embolism leading to stroke $[1,4]$. These findings were not confirmed in our study because no differences in cardiovascular complica- tions such as coronary obstruction, stroke, and death were observed. Interestingly, a trend towards improved mortality in patients with PD was noted. However, worse short- and long-term outcomes in patients without PD are possibly related to higher rates of blood transfusion and overall higher risk profile (logistic Euroscore I, NYHA class).

Post-implantation PVL is routinely assessed by control aortography and quantified according to VARC-2 criteria [20]. Echocardiography is helpful to identify the mechanism of PVL such as suboptimal frame expansion due to severe calcification in the native valve. The accurate assessment of $P V L$ is an important means for determining the effectiveness of procedure. To quantify PVL grade more accurately, besides angiography and echocardiography, we used the previously validated ARI, for which a cut-off value of 25 has been shown to be an independent predictor of one-year mortality after 


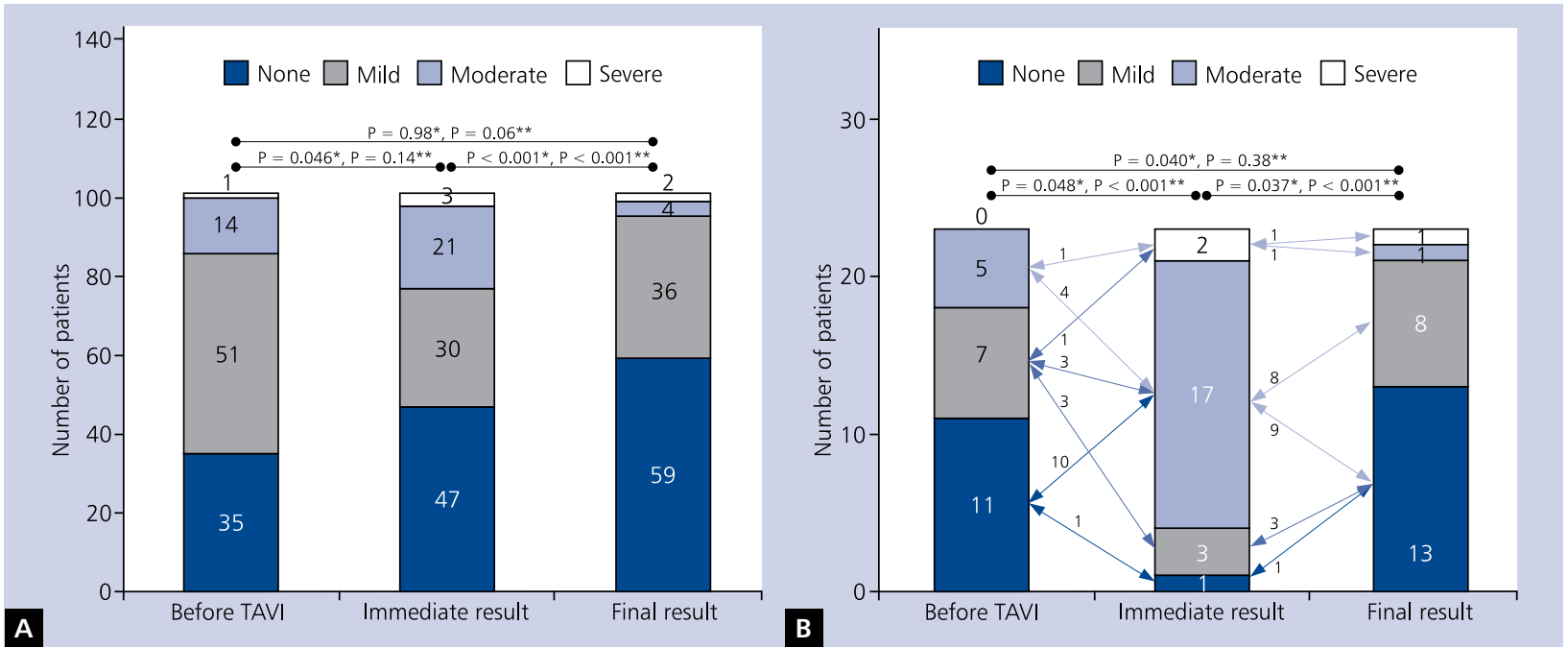

Figure 1. Severity of paravalvular leak (PVL) before and immediately after prosthesis deployment and at the end of the transcatheter aortic valve implantation (TAVI) procedure; A. For all patients; B. For patients requiring balloon post-dilatation); * $p$-value from $\chi^{2}$ test; ${ }^{* *}$ p-value from McNemar's test for changes in the proportions of patients with "none/mild" vs. "moderate/severe" PVL

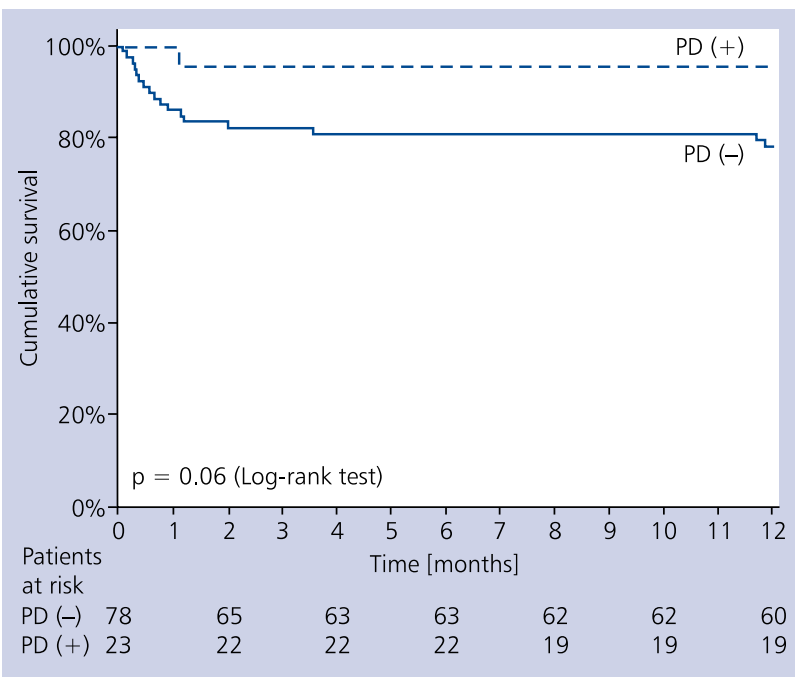

Figure 2. Kaplan-Meier curves for survival for patients stratified by the need for balloon post-dilatation (PD)

TAVI [9]. The ARI is a useful parameter to identify the need of PD but also to quantify the success of PD (additionally to imaging modalities) $[9,15]$. Moreover, recently Sinning et al. [27] have shown that ARI integrating pre- and post-procedural haemodynamic status increases the discriminatory value of post-procedural ARI and is useful to identify patients with unfavourable prognosis. The difference in radiation dose, fluoroscopy time, and contrast load between patients with and without PD may be caused by some differences in baseline characteristics and more frequent use of the transapical approach in the PD (+) group.

\section{Limitations of the study}

The present investigation represents a single-centre experience with a relatively small sample size, which could be regarded as a limitation of the study. Because the study was not randomised we can expect some important differences in baseline characteristics between the two groups, which may influence mortality as well as other clinical outcomes. The limited sample size did not allow us to use a propensity matching technique to control for selection bias. Thus, the results, especially in terms of clinical outcomes, should be considered exploratory and hypothesis generating. The ARI might be confounded by high systemic blood pressure, diastolic dysfunction, myocardial ischaemia during and after valve deployment or PD, as well as the use of vasopressors during TAVI, and other causes that may lead to an increase of LV end-diastolic pressure leading to false positive ARI. Likewise, the heart rate and its undeniable influence on the diastolic aortic blood pressure affects the ARI. In spite of several limitations, our study represents the complete analysis of consecutive patients without any exclusion criteria and with follow-up data available for all patients.

\section{CONCLUSIONS}

Balloon post-dilatation may be safe and effective technique to reduce moderate to severe PVL after TAVI.

\section{Conflict of interest: none declared}

\section{References}

1. Leon MB, Smith CR, Mack M, et al. PARTNER Trial Investigators. Transcatheter aortic-valve implantation for aortic stenosis in patients who cannot undergo surgery. N Engl J Med. 2010; 363(17): 1597-1607, doi: 10.1056/NEJMoa1008232, indexed in Pubmed: 20961243. 
2. Kleczyński P, Bagieński M, Sorysz D, et al. Short- and intermediate-term improvement of patient quality of life after transcatheter aortic valve implantation: a single-centre study. Kardiol Pol. 2014; 72(7): 612-616, doi: 10.5603/KP.a2014.0065, indexed in Pubmed: 24671914.

3. Kleczyński P, Bagieński M, Dziewierz A, et al. Twelve-month quality of life improvement and all-cause mortality in elderly patients undergoing transcatheter aortic valve replacement. Int J Artif Organs. 2016; 39(8): 444-449, doi: 10.5301/ijao.5000521, indexed in Pubmed: 27716868.

4. Kleczyński P, Zasada W, Bagieński M, et al. Paravalvular leak after transcatheter aortic valve implantation (TAVI): Short-term results. Data from Polish national POL-TAVI registry. Cardiol J. 2016; 23(2): 163-168, doi: 10.5603/CJ.a2015.0071, indexed in Pubmed: 26503080.

5. Schewel D, Frerker C, Schewel J, et al. Clinical impact of paravalvular leaks on biomarkers and survival after transcatheter aortic valve implantation. Catheter Cardiovasc Interv. 2015; 85(3): 502-514, doi: 10.1002/ccd.25295, indexed in Pubmed: 24259366.

6. Bagienski M, Kleczynski P, Dziewierz A, et al. Early- and mid-term outcomes after transcatheter aortic valve implantation. Data from a single-center registry. Adv Interv Cardiol. 2016; 12(2): 122-127, doi: 10.5114/aic.2016.59362, indexed in Pubmed: 27279871.

7. Athappan G, Patvardhan E, Tuzcu EM, et al. Incidence, predictors, and outcomes of aortic regurgitation after transcatheter aortic valve replacement: meta-analysis and systematic review of literature. J Am Coll Cardiol. 2013; 61(15): 1585-1595, doi: 10.1016/j.jacc.2013.01.047, indexed in Pubmed: 23500308.

8. Gotzmann M, Lindstaedt M, Mügge A. From pressure overload to volume overload: aortic regurgitation after transcatheter aortic valve implantation. Am Heart J. 2012; 163(6): 903-911, doi: 10.1016/j.ahj.2012.03.017, indexed in Pubmed: 22709742.

9. Sinning JM, Hammerstingl C, Vasa-Nicotera M, et al. Aortic regurgitation index defines severity of peri-prosthetic regurgitation and predicts outcome in patients after transcatheter aortic valve implantation. J Am Coll Cardiol. 2012; 59(13): 1134-1141, doi: 10.1016/j.jacc.2011.11.048, indexed in Pubmed: 22440213.

10. Van Belle E, Juthier F, Susen S, et al. FRANCE 2 Investigators. Postprocedural aortic regurgitation in balloon-expandable and self-expandable transcatheter aortic valve replacement procedures: analysis of predictors and impact on long-term mortality: insights from the FRANCE2 Registry. Circulation. 2014; 129(13): 1415-1427, doi: 10.1161/CIRCULATIONAHA.113.002677, indexed in Pubmed: 24566199.

11. Stokłosa P, Szymański P, Dąbrowski M, et al. The impact of transcatheter aortic valve implantation on left ventricular performance and wall thickness - single-centre experience. Post Kardiol Interw. 2015; 11(1): 37-43, doi: 10.5114/pwki.2015.49183, indexed in Pubmed: 25848369.

12. Bochenek T, Kusz B, Mizia M, et al. Echocardiographic evaluation of myocardial strain in patients after transcatheter aortic valve implantation. Post Kardiol Interw. 2015; 11(2): 95-99, doi: 10.5114/pwki.2015.52281, indexed in Pubmed: 26161100.

13. Abdel-Wahab M, Zahn R, Horack M, et al. German transcatheter aortic valve interventions registry investigators. Aortic regurgitation after transcatheter aortic valve implantation: incidence and early outcome. Results from the German transcatheter aortic valve interventions registry. Heart. 2011; 97(11): 899-906, doi: 10.1136/hrt.2010.217158, indexed in Pubmed: 21398694.

14. Moat NE, Ludman P, de Belder MA, et al. Long-term outcomes after transcatheter aortic valve implantation in high-risk patients with severe aortic stenosis: the U.K. TAVI (United Kingdom Transcatheter Aortic Valve Implantation) Registry. J Am Coll Car- diol. 2011; 58(20): 2130-2138, doi: 10.1016/j.jacc.2011.08.050, indexed in Pubmed: 22019110.

15. Stundl A, Rademacher MC, Descoups C, et al. Balloon post-dilation and valve-in-valve implantation for the reduction of paravalvular leakage with use of the self-expanding CoreValve prosthesis. EuroIntervention. 2016; 11(10): 1140-1147, doi: 10.4244/EIJY15M11_04, indexed in Pubmed: 26561518.

16. Sinning JM, Stundl A, Pingel S, et al. Evaluation and management of paravalvular aortic regurgitation after transcatheter aortic valve replacement. J Am Coll Cardiol. 2013; 62(1): 11-20, doi: 10.1016/j.jacc.2013.02.088, indexed in Pubmed: 23644081.

17. Nombela-Franco L, Rodés-Cabau J, DeLarochellière R, et al. Predictive factors, efficacy, and safety of balloon post-dilation after transcatheter aortic valve implantation with a balloon-expandable valve. JACC Cardiovasc Interv. 2012; 5(5): 499-512, doi: 10.1016/j.jcin.2012.02.010, indexed in Pubmed: 22625188.

18. Eggebrecht H, Doss M, Schmermund A, et al. Interventional options for severe aortic regurgitation after transcatheter aortic valve implantation: balloons, snares, valve-in-valve. Clin Res Cardiol. 2012; 101(6): 503-507, doi: 10.1007/s00392-012-0434-4, indexed in Pubmed: 22476821.

19. Webb JG, Binder RK. Post-dilating transcatheter heart valves. JACC Cardiovasc Interv. 2012; 5(5): 513-514, doi: 10.1016/j.jcin.2012.02.011, indexed in Pubmed: 22625189.

20. Kappetein AP, Head SJ, Généreux P, et al. Valve Academic Research Consortium-2. Updated standardized endpoint definitions for transcatheter aortic valve implantation: the Valve Academic Research Consortium-2 consensus document. EuroIntervention. 2012; 8(7): 782-795, doi: 10.4244/EIJV8I7A121, indexed in Pubmed: 23022744.

21. Kleczynski P, Dziewierz A, Bagienski M, et al. Impact of coronary artery disease burden on 12-month mortality of patients after transcatheter aortic valve implantation. J Interv Cardiol. 2016; 29(4): 375-381, doi: 10.1111/joic.12308, indexed in Pubmed: 27358194.

22. Koskinas KC, Stortecky S, Franzone A, et al. Post-Procedural troponin elevation and clinical outcomes following transcatheter aortic valve implantation. J Am Heart Assoc. 2016; 5(2): e002430, doi: 10.1161/JAHA.115.002430, indexed in Pubmed: 26896474.

23. Takagi K, Latib A, Al-Lamee R, et al. Predictors of moderate-to-severe paravalvular aortic regurgitation immediately after CoreValve implantation and the impact of postdilatation. Catheter Cardiovasc Interv. 2011; 78(3): 432-443, doi: 10.1002/ccd.23003, indexed in Pubmed: 21793168.

24. Daneault B, Koss E, Hahn RT, et al. Efficacy and safety of postdilatation to reduce paravalvular regurgitation during balloon-expandable transcatheter aortic valve replacement. Circ Cardiovasc Interv. 2013; 6(1): 85-91, doi: 10.1161/CIRCINTERVENTIONS.112.971614, indexed in Pubmed: 23339841.

25. O'Sullivan KE, Gough A, Segurado R, et al. Is valve choice a significant determinant of paravalular leak post-transcatheter aortic valve implantation? A systematic review and meta-analysis. Eur J Cardiothorac Surg. 2014; 45(5): 826-833, doi: 10.1093/ejcts/ezt515, indexed in Pubmed: 24186923.

26. De Carlo M, Giannini C, Fiorina C, et al. Paravalvular leak after CoreValve implantation in the Italian Registry: predictors and impact on clinical outcome. Int J Cardiol. 2013; 168(5): 5088-5089, doi: 10.1016/j.ijcard.2013.07.184, indexed in Pubmed: 23931977

27. Sinning JM, Stundl A, Pingel S, et al. Pre-procedural hemodynamic status improves the discriminatory value of the aortic regurgitation index in patients undergoing transcatheter aortic valve replacement. JACC Cardiovasc Interv. 2016; 9(7): 700-711, doi: 10.1016/j.jcin.2015.12.271, indexed in Pubmed: 27056309.

Cite this article as: Kleczyński P, Dziewierz A, Daniec M, et al. Impact of post-dilatation on the reduction of paravalvular leak and mortality after transcatheter aortic valve implantation. Kardiol Pol. 2017; 75(8): 742-748, doi: 10.5603/KP.2017.0152. 


\title{
Wpływ doprężenia na zmniejszenie przecieku okołozastawkowego i śmiertelność po przezskórnej implantacji zastawki aortalnej
}

\author{
Paweł Kleczyński, Artur Dziewierz, Marzena Daniec, Maciej Bagieński, Łukasz Rzeszutko, \\ Danuta Sorysz, Jarosław Trębacz, Robert Sobczyński, Marek Tomala, Dariusz Dudek \\ Instytut Kardiologii, Uniwersytet Jagielloński, Collegium Medicum, Kraków
}

\section{Streszczenie}

Wstęp: Przeciek okołozastawkowy (PVL) jest jednym z istotnych powikłań po zabiegu przezskórnej implantacji zastawki aortalnej (TAVI) i może wpływać na rokowanie odległe pacjentów.

Cel: Celem niniejszej pracy była ocena efektów doprężenia balonem (PD) na stopień PVL i śmiertelność u pacjentów po TAVI. Metody: Do badania włączono 101 pacjentów po TAVI. Do oceny PVL użyto parametrów angiograficznych, echokardiograficznych i wskaźnika niedomykalności aortalnej (ARI). Pacjentów podzielono na dwie grupy, w zależności od tego, czy wykonano doprężenie. Oceniano stopień redukcji PVL, ARI i śmiertelność.

Wyniki: Doprężenie balonem wykonano u 23 (22,8\%) pacjentów. W 95,6\% przypadkach redukcja PVL była skuteczna (brak lub mały PVL). Odnotowano wzrost ARI z 23,4\% (22,4-24,0) do 27,1\% (26,1-28,3); $\mathrm{p}<0,001$. 30-dniowa śmiertelność wyniosła $14,1 \%$ w grupie PD (-) vs. $0,0 \%$ w grupie PD (+); $p=0,07$. Śmiertelność po 12 miesiącach $(21,8 \%$ vs. 4,3\%; $p=0,97)$ i częstość udaru związanego z zabiegiem $(7,7 \%$ vs. 8,7\%; $p=0,99)$ nie były statystycznie różne między grupami. Wnioski: Doprężenie balonem może być bezpieczną i skuteczną techniką służącą do zmniejszenia stopnia PVL po TAVI. Słowa kluczowe: stenoza aortalna, przezskórna implantacja zastawki aortalnej, przeciek okołozastawkowy, postdylatacja

Kardiol Pol 2017; 75, 8: 742-748 